FACTA UNIVERSITATIS

Series: Physical Education and Sport, Vol. 18, No 2, 2020, pp. 475 - 481

https://doi.org/10.22190/FUPES200607045H

Research article

\title{
PHYSICAL ACTIVITY LEVELS IN PHYSICAL EDUCATION TEACHERS BEFORE AND DURING SCHOOL SUSPENSION BROUGHT BY THE COVID-19 QUARANTINE
}

\author{
UDC 796: 615.01
}

\begin{abstract}
Javier Arturo Hall-López
Faculty of Sports Autonomous University of Baja California, Mexico City, Mexico

Abstract. The aim of this paper was to compare the physical activity (PA) levels in physical education $(P E)$ teachers before and during school suspension brought by the COVID-19 quarantine. Thirty-seven PE teachers participated in the descriptive crosssectional comparative methodological design study. In order to evaluate the PA levels, the International Physical Activity Questionnaire (IPAQ) was applied. As a statistical method, the equality of variance was calculated using the Student t test for independent samples. The results revealed less total PA MET-minutes/week in PE teachers $(p=.005)$, with a percentage difference of $69.84 \%$, during the COVID-19 quarantine compared to the state before the COVID-19 pandemic. PE teachers are considered professionals who help public health by reducing sedentary lifestyle in society. In that context, decrement in PA level, i.e., their inactivity determined during the COVID-19 pandemic is unacceptable.
\end{abstract}

Key words: Teacher, Physical Education, Physical Activity, COVID-19.

\section{INTRODUCTION}

The quarantine meant to prevent the spread of COVID-19 has limited the daily practice of physical activity (PA) in the population (Blocken, Malizia, van Druenen, \& Marchal, 2020). To battle this problem, and maintain the health benefits, PA at home through physical exercise of different modalities has been recommended (Halabchi, Ahmadinejad, \& Selk-Ghaffari, 2020), such as resistance training with one's own weight, aerobic exercise, dancing, using ergometer stationary bicycles (Hammami, Harrabi, Mohr, \& Krustrup, 2020), as well as relying on technology with audiovisual material from the internet, and mobile applications for guidance and motivation to perform PA (Tate, Lyons, \& Valle, 2015). In addition, exercise

Received June 07, 2020 / Accepted September 10, 2020

Corresponding author: Javier Arturo Hall-López

Faculty of Sports of the Autonomous University of Baja California, Avenida Alvaro Obregon Sin Numero, Colonia Nueva Mexicali, 21100, Baja California, Mexico,

Phone: + 52 (686) $5518200 \cdot$ E-mail: javierhall@uabc.edu.mx 
during quarantine has also been recommended due to the negative mental, and physical consequences of a sedentary lifestyle brought by the quarantine (Jiménez-Pavón, CarbonellBaeza, \& Lavie, 2020).

For adults, the World Health Organization (WHO) recommends a minimum of 150 minutes per week for the practice of moderate intensity aerobic PA, or 75 minutes of vigorous aerobic PA per week (Arias-Palencia et al., 2015). It is estimated that due to the physical inactivity of the population caused by the COVID-19 quarantine, there will be an increase in cardiovascular diseases associated with a sedentary lifestyle (Lippi, Henry, \& Sanchis-Gomar, 2020). In this sense, the physical education (PE) teacher is considered a professional from the field of education in the public health context who contributes to the reduction of this problem (Webster et al., 2015). In the case of teachers, a systematic review which included them reports that PA is considered positive for their health (Rosales Ricardo et al., 2016). Even though, high levels of PA in teachers is related to a better quality of life (Gümüş \& Isik, 2018), the presence of $53 \%$ to $73 \%$ of a sedentary lifestyle, or low levels of PA among teachers, has been reported in Latin America (Rodríguez Guzmán, Díaz Cisneros, \& Rodríguez Guzmán, 2015). A research reports higher practice of PA and less sedentary behavior in people with outdoor occupations (Smith, et al., 2016), as PE teachers whose level of PA has been assessed, reporting $27 \%$ with low levels of PA (Hall López, Ochoa Martínez, Sáenz-López Buñuel, \& Monreal Ortiz, 2009).

The aim of this paper is to compare the PA levels in PE teachers before and during school suspension brought by the COVID-19 quarantine.

\section{METHODS}

\section{Participants}

A total of 37 teachers participated (22 men and 15 women), age $27.8 \pm 6.1$ years (Mean \pm SD), and teaching experience of $6.4 \pm 3.3$ years $(\mathrm{Mean} \pm \mathrm{SD}$ ) in the public and private educational system in the city of Mexicali, Baja California, Mexico.

The present study was approved and registered in the Office of Graduate Studies and Research of the Autonomous University of Baja California (Protocol No. 149/1823), under a cross-sectional methodological design, with non-probability sampling for convenience (Thomas, Nelson, \& Silverman, 2015), following the ethical principles of the research involving human subjects of the declaration of Helsinki (Puri, Suresh, Gogtay, \& Thatte, 2009).

\section{Procedures}

In the educational context, information and communication technologies have been essential to managing learning (Lorgelly \& Adler, 2020). Regarding the field of health, attempts have been made to identify the PA level in people who exercise during the COVID-19 quarantine by means of questionnaires (de Oliveira Neto et al., 2020). In a technological context, the current study utilized Google Drive as a teaching tool to assess PA at a distance (Álvarez Ferrón \& Sánchez Cañizares, 2014), using the International Physical Activity Questionnaire-IPAQ (Craig, et al. 2003), and comparing the PA levels of PE teachers before and during the quarantine caused by COVID-19.

The responses to the IPAQ questionnaire were recreated, classifying the score into three categories: low, moderate, and high. According to the methodology, the PA performed in 
the last 7 days was categorically and continuously measured. The continuous score was estimated using a weekly energy expenditure (minutes/week) expressed as a metabolic equivalent (MET). This was obtained by multiplying the value of energy expenditure for PA according to the weekly frequency (days per week), and the time in minutes (minutes per day), valuing the modalities of walking in an average of $3.3 \mathrm{MET}$, all the PA of moderate intensity with a value of $4 \mathrm{MET}$, and PA of vigorous intensity with a value of 8 MET.

\section{Statistical analysis}

Descriptive statistics was in use In order to determine the percentage difference $(\Delta \%)$ before and during the COVID-19 quarantine ([(Average-2 - Average-1) / Media-1] $\times 100$ ) (Vincent, 2012). For inferential statistical analysis, the normality of the groups, and the homogeneity of the variance of the data were verified using the Shapiro-Wilk test with the level of the significance set at 0.05; As a cross-sectional study when comparing as fixed variables of two groups 1) before the COVID-19 quarantine or 2) during the COVID-19 quarantine, and PA performed by PE teachers as a numerical random variable. The student's t-test for independent samples calculating the equality of the variance was utilized, establishing the level of the significance $\alpha \leq 0.05$.

\section{RESULTS}

The percentage distribution of the level of PA in PE Teachers before and during the COVID-19 social distancing is presented in Table 1.

Table 1 Category of PA in percentage, before and during quarantine by COVID-19 in PE teachers

\begin{tabular}{lcc}
\hline Physical Activity Level & Before COVID-19 & During COVID-19 \\
\hline Low & $25.2 \%$ & $49.8 \%$ \\
Moderate & $37.8 \%$ & $25.5 \%$ \\
High & $37 \%$ & $24.7 \%$ \\
\hline
\end{tabular}

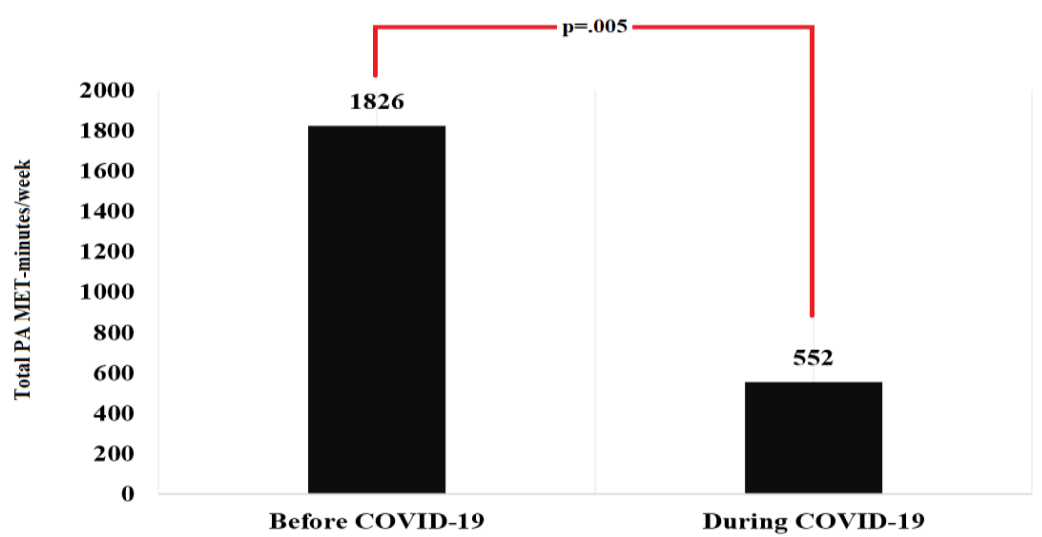

Fig. 1 Total PA MET-minutes/week=sum of Low+Moderate+High PA levels, before and during the COVID-19 quarantine in PE teachers $(\mathrm{p}=.005)$. 
Figure 1 reflects the results of the student's t-test for independent samples, calculating the equality of the variance of total PA MET-minutes/week, before (1826) and during (552) the COVID-19 quarantine in PE teachers, significant differences values where found $(\mathrm{p}=.005)$. Figure 2 shows the percentages difference $(\Delta \%)$ by category of low, moderate, and high PA levels.

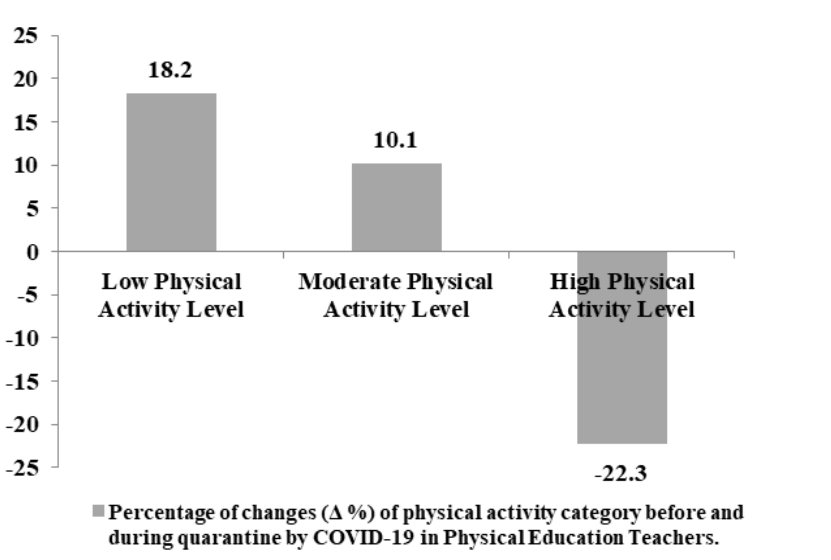

Fig. 2 Percentage change $(\Delta \%)$ of PA category before and during the COVID-19 quarantine in PE.

\section{DISCUSSION}

The main result of this research was that the level of PA MET-minutes/week of PE teachers decreased during the COVID-19 quarantine (69.8 $\Delta \%$ ). Hence, due to limitations brought by the COVID-19 quarantine, the possibilities of doing PA in different modalities were lower (Blocken et al., 2020). In Mexico, according to the national health and nutrition surveys, nearly $50 \%$ of adults spend more than two hours a day in front of a screen, occupying an average of $1 \mathrm{~h} 40 \mathrm{~min}$ of their day in motorized transportation, and at least 3h30min of their time sitting (Medina, Janssen, Campos, \& Barquera, 2013). When comparing the level of PA percentages reported by research that also evaluated PE teachers using the IPAQ questionnaire as a methodological instrument, values with similar trends can be observed in the low, moderate, and high categories (Hall-López et al. 2009). Another study that evaluated professionals in the teaching of physical culture reported similar PA percentages (Hall-López, Ochoa Martínez, \& Alarcón Meza, 2012).

PE teachers work mostly of the time in outdoors environment, and according to Smith et al. (2016), professions and occupations with less energy expenditure, and more presence of sedentary behaviors work in indoor environments. Hypothetically, it is inferred that suspension of school activities due to social distancing in the population, is associated with PA reduction in PE teachers (Ramos, 2020), since it has been documented that the energy expenditure made by teachers during PE class also comes with lighter activities such as office work, and PA with moderate energy expenditure when conducting, supervising, and monitoring PE classes (Trudeau, Laurencelle, \& Lajoie, 2015). It has been documented i.e., evaluated by pedometers, that in a PE class of the first and the second grade of primary 
school, a teacher walks on average 925 steps (Rodriguez-Negro, \& Yanci, 2019). According to Rodriguez-Negro \& Yanci (2017) teacher makes 1020 steps per session in 90-minute sessions according to the manual-eye coordination content taught, a balance content of 864.67 steps per session, and body expression of 591.25 steps per session. When conducting PE classes using analytical and global methodologies, the number of steps was of 1296 in motor activities content, and of 1493 in basketball content (Rodriguez-Negro \& Yanci, 2017). Concerning Mexican PE teachers, Ochoa-Martínez, Hall-López, Campos, \& Meza (2020) determined that they should increase PA level of the students during the PE class, respecting the recommendations for children and adolescents established by the WHO for the achievement of a minimum of 60 minutes of PA in a day of moderate to vigorous intensity.

The Google Drive tool was utilized in a timely manner to assess the level of PA (Álvarez Ferrón \& Sánchez Cañizares, 2014) in two moments of the COVID-19 health crisis. Limitation of the study is low number of the participants. Performing a crosssectional design without inferring into other causal variables, and only addressing teachers in the Mexican educational context, is however, a reliable, valid, low-cost assessment instrument, with values easily comparable to other studies due to it being an international questionnaire (Craig et al., 2003).

PE teacher is among the groups of professions with optimal levels of physical condition, particularly aerobic capacity (Chen \& Yan, 2017). Regarding PA performed in PE class, the factors that promote intensity are diverse and multifactorial (McKenzie, \& van der Mars, 2015). Nevertheless, from the educational field, PE teachers are considered professionals who help in the context of public health to reduce sedentary lifestyles (Webster et al., 2015). It is a reason for which we consider it paradoxical for them to present physical inactivity patterns similar to those of the general population (Medina, et al., 2013), even though during the COVID-19 quarantine, the level of PA in the PE teachers evaluated decreased. Reason for which it is important to follow the recommendations for physical distancing to avoid COVID19, and increase the level of PA from home (Hammami et al., 2020).

\section{CONCLUSION}

During school suspension caused by COVID-19 infection, PA MET-minutes/week of PE teachers decreased significantly. PE teachers are considered professionals who help public health by reducing sedentary lifestyle in society. In that context, decrement in PA level, i.e., their inactivity determined during COVID-19 pandemics is inacceptable.

\section{REFERENCES}

Álvarez Ferrón, M., \& Sánchez Cañizares, L. (2014). Conocimiento, valoración y utilización, por parte del alumnado, de Google Drive como herramienta de trabajo cooperativo (Knowledge, evaluation and use, by students, of Google Drive as a tool for cooperative work). Enseñanza \& Teaching, 32(2), 23-52.

Arias-Palencia, N.M., Solera-Martinez, M., Gracia-Marco, L., Silva, P., Martinez-Vizcaino, V., Canete-GarciaPrieto, J., et al. (2015). Levels and patterns of objectively assessed physical activity and compliance with different public health guidelines in university students. PLoS One, 10(11), e0141977.

Blocken, B., Malizia, F., van Druenen., T., \& Marchal, T. (2020). Towards aerodynamically equivalent COVID-19 $1.5 \mathrm{~m}$ social distancing for walking and running. Urban Physics, Wind Engineering \& Sports Aerodynamics. Preprint, 1-12.

Chen, J., \& Yan, L. (2017). Oxygen consumption and energy expenditure in physical education teachers. International Journal of Recent Engineering Science, 4(1), 11-16. 
Craig, C.L., Marshall, A.L., Sjostrom, M., Bauman, A.E., Booth, M.L., Ainsworth, B.E., et al. (2003). International physical activity questionnaire: 12-country reliability and validity. Medicine \& Science in Sports \& Exercise, 35(8), 1381-1395.

de Oliveira Neto, L., de Oliveira Tavares, V. D., Schuch, F. B., \& Lima, K. C. (2020). Coronavirus Pandemic (SARS-COV-2): Pre-Exercise Screening Questionnaire (PESQ) for Telepresential Exercise. Frontiers in public health, 8,146

Gümüş, H., \& Isik, O. (2018). The relationship of physical activity level, leisure motivation and quality of life in candidate teachers. International Journal of Progressive Education. 14(5), 22-32.

Halabchi, F., Ahmadinejad Z., \& Selk-Ghaffari, M. (2020). COVID-19 epidemic: Exercise or not to exercise; That is the question!. Asian Journal of Sports Medicine, 11(1), e102630.

Hall-López, J.A., Ochoa Martínez, P.Y., \& Alarcón Meza, E.I. (2012). Actividad física, estado nutricional y obesidad abdominal en profesores del área de la cultura física (Physical activity, nutritional state and abdominal obesity in physical culture professors field). Revista Internacional de Medicina y Ciencias de la Actividad Física y el Deporte, 12(46) 209-220. In Spanish

Hall-López, J., Ochoa Martínez, P., Sáenz-López Buñuel, P., \& Monreal Ortiz, L. (2009). Estudio comparativo del nivel de actividad física, estado nutricio y obesidad abdominal en profesores de educación física de la Universidad Autónoma de Sinaloa y la Universidad de Huelva (Comparative study of the physical activity level, nutrition state and abdominal obesity in physical education professors from the University Autonomus of Sinaloa and Huelva University). Retos, O(15), 5-8. In Spanish

Hammami, A., Harrabi, B., Mohr, M., \& Krustrup, P. (2020). Physical activity and coronavirus disease 2019 (COVID-19): specific recommendations for home-based physical training. Managing Sport and Leisure, 4, 1-6.

Lippi, G., Henry, B.M., \& Sanchis-Gomar, F. (2020). Physical inactivity and cardiovascular disease at the time of coronavirus disease 2019 (COVID-19). European Journal of Preventive Cardiology, 0(0) 1-3.

Lorgelly, P.K., \& Adler, A. (2020). Impact of a global pandemic on health technology assessment. Applied Health Economics and Health Policy, 18, 339-343.

Jiménez-Pavón, D., Carbonell-Baeza, A., \& Lavie, C.J. (2020). Physical exercise as therapy to fight against the mental and physical consequences of COVID-19 quarantine: Special focus in older people. Progress in Cardiovascular Diseases, S0033-0620(20), 30063-3.

McKenzie, T.L., \& van der Mars, H. (2015). Top 10 research questions related to assessing physical activity and its contexts using systematic observation. Research Quarterly for Exercise and Sport, 86(1), 13-29.

Medina, C., Janssen, I., Campos, I. \& Barquera, S. (2013). Physical inactivity prevalence and trends among Mexican adults: results from the National Health and Nutrition Survey (ENSANUT) 2006 and 2012. BMC Public Health, 13(1), 1063, 1-10.

Ochoa-Martínez, P.Y., Hall-López, J.A., Campos, C.E.L., \& Meza, E.I.A. (2020). Perceived exertion and moderate to vigorous physical activity in middle school students according to the physical education teachers' experience. Facta Universitatis Series Physical Education and Sport, 18(1), 179-188.

Puri, K.S., Suresh, K.R., Gogtay, N.J., \& Thatte, U.M. (2009). Declaration of Helsinki, 2008: Implications for stakeholders in research. Journal of Postgraduate Medicine, 55(2), 131-134.

Ramos, C. (2020). Covid-19: la nueva enfermedad causada por un coronavirus (Covid-19: The new disease caused by a coronavirus). Salud Pública de México, 62(2), 225-227. In Spanish

Rodríguez Guzmán, L., Díaz Cisneros, F.J., \& Rodríguez Guzmán, E. (2015). Estudio exploratorio sobre actividad física en profesores latinoamericanos (Exploratory study on physical activity in Latin american teachers). Revista Edu-Fisica, 7(15), 14-22. In Spanish

Rodríguez-Negro, J., \& Yanci, J. (2017). The study of physical education teachers' walked distances in relation to students' ages and the time of day. Chapters 5 and 6. In: R.V. Nata (Ed.). Progress in education (Volume 47). Nova Science Publishers.

Rodriguez-Negro, J., \& Yanci, J. (2019). Nivel de actividad física realizada por docentes de educación física en las sesiones impartidas en el primer y segundo curso de educación primaria (Physical activity level of physical education teachers during lessons taught in primary education first an. Retos, 35, 213-215. In Spanish

Rosales Ricardo, Y., Orozco, D., Yaulema, L., Parreño, Á., Caiza, V., Barragán, V., et al. (2016). Actividad física y salud en docentes. Una revisión (Physical activity and health in teachers. A review). Apunts. Medicina de l'Esport, 52(196), 159-166. In Spanish

Smith, L., McCourt, O., Sawyer, A., Ucci, M., Marmot, A., Wardle, J., et al. (2016). A review of occupational physical activity and sedentary behaviour correlates, Occupational Medicine, 66(3), 185-192.

Tate, D.F., Lyons, E.J., \& Valle, C.G. (2015). High-tech tools for exercise motivation: use and role of technologies such as the internet, mobile applications, social media, and video games. Diabetes Spectrum, 28(1), 45-54.

Thomas, J.R., Nelson, J.K., \& Silverman, S.J. (2015). Research methods in physical activity (7 ${ }^{\text {th }}$ Edition). Human Kinetics. Champaign, Ilinois: Human Kinetics. 
Physical Activity Levels in Physical Education Teachers Before and During School Suspension Brought... 481

Trudeau, F., Laurencelle, L., \& Lajoie, C. (2015). Energy expenditure at work in physical education teachers. Applied Ergonomics, 46 (Part A), 218-223.

Vincent W.J. (2012). Statistics in kinesiology (4 $4^{\text {th }}$ Edition). Champaign, Ilinois: Human Kinetics.

Webster, C.A., Webster, L., Russ, L., Molina, S., Lee, H., \& Cribbs, J. (2015). A systematic review of public health-aligned recommendations for preparing physical education teacher candidates. Research Quarterly for Exercise and Sport, 86(1), 30-39.

\section{NIVOI FIZIČKE AKTIVNOSTI NASTAVNIKA FIZIČKOG VASPITANJA PRE I TOKOM OBUSTAVE NASTAVE USLED COVID-19 KARANTINA}

Cilj ovog rada bio je da se uporede nivoi fizičke aktivnosti (FA) nastavnika fizičkog vaspitanja (FV) pre $i$ za vreme obustave nastave usled COVID-19 karantina. Korišćcn je deskriptivni transferzalni komparativni metodološki pristup u istraživanju u kome je učestvovalo trideset sedam nastavnika FV. U proceni nivoa FA primenjen je Međunarodni upitnik za fizičku aktivnost (IPAQ). U statističkoj obradi podataka korišćen je studentov t test za nezavisne uzorke. Rezultati ukazuju na manji ukupni nivo FA nastavnika FV izražen u MET-minuta/nedeljno, tokom karantina usled COVID-19, u odnosu na vreme pre karantina ( $p=.005$ ), sa razlikom od $69.84 \%$. Nastavnici FV smatraju se profesionalcima koji pomažu javno zdravlje umanjujući sedentarni način života $u$ društvu. U tom kontekstu, utvrđeno smanjenje nivoa FA, tj., njihova neaktivnost tokom COVID-19 pandemije je neprihvatljivo.

Ključne reči: nastavnik, fizičko vaspitanje, fizička aktivnost, COVID-19 